\title{
Analisis Sensitivitas AHP-SAW dan ROC-SAW dalam Pengambilan Keputusan Multikriteria
}

\author{
I Gede Iwan Sudipa ${ }^{1 *}$, Ida Ayu Dwi Puspitayani² \\ 1,2 Teknik Informatika - STMIK STIKOM Indonesia
}

\author{
A R T I C L E I N F O \\ Article history: \\ Received 19 April 2019 \\ Received in revised form \\ 10 May 2019 \\ Accepted 12 June 2019 \\ Available online 25 July \\ 2019 \\ Kata Kunci: \\ Analisis Sensitivitas, AHP- \\ SAW, ROC-SAW \\ Multikriteria \\ Keywords: \\ Sensitivity Analysis, AHP- \\ SAW, ROC-SAW, Multi \\ Criteria
}

\begin{abstract}
A B S T R A K
Beasiswa merupakan salah satu upaya yang dilakukan pemerintah dalam mendorong dan membantu potensi kemajuan pendidikan di negara Indonesia, salah satunya adalah beasiswa Peningkatan Prestasi Akademik(PPA) sehingga diperlukan seleksi penerima beasiswa untuk menentukan penerima beasiswa yang sesuai dengan kriteria penilaian. Permasalahan seleksi beasiswa termasuk kedalam permasalahan Multi Attribute Decision Making (MADM). Penelitian ini menganalisis masalah MADM yaitu pemberian beasiswa dengan menggunakan kombinasi metode Analytical Hierarchy Process (AHP), Simple Additive Weighting(SAW) dan model pemberian bobot Rank Order Centroid(ROC). Pengujian metode yang sesuai dilakukan dengan melakukan analisis sensitivitas untuk mengetahui kombinasi metode yang paling sensitif dalam menghasilkan perankingan akhir penerima beasiswa. Dari hasil pengujian analisis sensitivitas kombinasi ROC-SAW menghasilkan nilai sensitivitas terkecil dengan nilai 0.000144 , dan dari 18 percobaan perubahan bobot yang dilakukan untuk mengetahui perubahan ranking hasil akhir didapatkan hasil bahwa metode AHP-SAW menghasilkan perubahan ranking dengan persentase $80,56 \%$ dari ranking awal, dan ROC-SAW menghasilkan perubahan ranking dengan persentase $90,83 \%$ dari ranking awal.
\end{abstract}

\section{A B S T R A C T}

Scholarship is one of the efforts made by the government in encouraging and assisting the potential for advancement of education in the country of Indonesia, one of which is an Academic Achievement Improvement scholarship (PPA) so that scholarship recipient selection is needed to determine scholarship recipients in accordance with the assessment criteria. Scholarship selection issues are included in the Multi Attribute Decision Making (MADM) problem. This study analyzes the MADM problem of scholarships by using a combination of Analytical Hierarchy Process (AHP), Simple Additive Weighting (SAW) and Rank Order Centroid (ROC) weighting models. Testing the appropriate method is done by conducting a sensitivity analysis to determine the combination of the most sensitive methods in producing the final ranking of scholarship recipients. From the results of testing the sensitivity analysis of the combination of ROC-SAW produces the smallest sensitivity value with a value of 0.000144 , and from 18 trials of weight changes carried out to determine changes in the final ranking results obtained that the AHP-SAW method results in ranking changes with a percentage of $80.56 \%$ from the initial ranking, and ROC-SAW resulted in ranking changes with a percentage of $90.83 \%$ from the initial ranking.

\footnotetext{
* Corresponding author.

E-mail addresses: iwansudipa@stiki-indonesia.ac.id (I Gede Iwan Sudipa)
} 


\section{Pendahuluan}

Pendidikan merupakan sektor utama yang mendorong perkembangan kemajuan suatu bangsa, khususnya bangsa Indonesia. Pendidikan dinilai sangat penting, namun terkadang tidak semua orang dapat menempuh pendidikan yang diharapkan. Untuk mengatasi masalah tingginya biaya pendidikan, maka Direktorat Jenderal Tinggi Kementrian Pendidikan Nasional dan Kebudayaan melalui perguruan tinggi negeri atau swasta, yayasan atau perusahaan swasta, mengalokasikan dana untuk memberikan bantuan biaya pendidikan kepada mahasiswa yang orangtuanya tidak mampu untuk membiayai dan mahasiswa yang mempunyai prestasi tinggi, baik akademik maupun non akademik dalam bentuk beasiswa. Menurut Pedoman Beasiswa dan Bantuan Biaya Pendidikan PPA (Jenderal, Dan, Riset, \& Tinggi, 2015) menjelaskan bahwa beasiswa Peningkatan Prestasi Akademik (PPA) adalah dukungan biaya pendidikan yang diberikan kepada mahasiswa untuk mengikuti dan/atau menyelesaikan pendidikan tinggi berdasarkan pertimbangan utama prestasi dan/atau potensi akademik, sedangkan Bantuan Biaya Pendidikan Peningkatan Prestasi Akademik (BBP PPA) adalah dukungan biaya pendidikan yang diberikan kepada mahasiswa untuk mengikuti dan/atau menyelesaikan pendidikan tinggi berdasarkan pertimbangan utama keterbatasan kemampuan ekonomi.

Salah satu metode yang digunakan dalam penentuan keputusan adalah Multi Attribute Decision Making (MADM), MADM merupakan bagian dari metodologi Multi Criteria Decision Making (MCDM) yang secara khusus digunakan dalam penentuan keputusan dengan banyak kriteria, atribut serta banyak alternatif(C. H. Yeh, 2003). Didalam model MCDM terdapat beberapa metode yaitu Analytic Hierarchy Process (AHP), Rank Order Centroid (ROC) dan Simple Additive Weighting (SAW) yang dapat digunakan dalam penentuan keputusan, AHP dan ROC merupakan metode yang digunakan untuk penentuan bobot kriteria, subkriteria, dan atribut(C. Yeh \& Willis, 2001). SAW merupakan metode perankingan yang didasarkan atas penjumlahan terbobot. Gabungan dari ketiga metode tersebut diharapkan dapat menghasilkan keputusan yang obyektif serta dapat memberikan perbandingan hasil dengan hasil yang dibuat pengambil keputusan, hasil dari sebuah sistem pendukung keputusan bukan menggantikan keputusan pengambil keputusan melainkan membantu pengambil keputusan dalam melakukan perbandingan hasil.

Penelitian ini bertujuan untuk menyelesaikan permasalahan seleksi pemberian beasiswa dengan menggunakan kombinasi metode AHP-SAW dan ROC-SAW, serta menentukan metode yang sesuai dengan penyelesaian dan pengujian analisis sensitivitas untuk setiap metode.

\section{Metode}

\section{A. Prosedur AHP}

Prosedur yang dilakukan pada tahap ini adalah : menentukan kriteria dari alternatif-alternatif yang kemudian menyusunnya menjadi satu hirarki. Membuat matriks pairwise comparison berdasarkan kriteria dan alternatif dengan skala penilaian sehingga akan diperoleh nilai pendapat dalam bentuk angka, skala perbandingan. Prosedur dasar AHP terdiri dari beberapa langkah sebagai berikut(Chun, Huang, \& Wang, 2009):

1. Membuat matriks perbandingan berpasangan

Tabel 1. Matriks Perbandingan Berpasangan

\begin{tabular}{ccccc}
\hline K & K1 & K2 & $\ldots$ & Kn \\
K1 & b11 & b12 & $\ldots$ & b1n \\
K2 & b21 & b22 & $\ldots$ & b2n \\
$\ldots$ & $\ldots$ & $\ldots$ & Bij & $\ldots$ \\
Kn & bn1 & bn2 & $\ldots$ & bnn \\
\hline
\end{tabular}

Mengalikan masing-masing element pada masing-masing baris matriks perbandingan, dan

hasilnya adalah $\mathrm{M}_{\mathrm{i}}$ dengan menggunakan persamaan $\mathrm{M}_{\mathrm{i}}=\prod_{j=1}^{n}$ bij $j_{x} \mathrm{i}=1,2, \ldots, \mathrm{n}$

2. Menghitung $n$ akar pangkat dari Mi dengan persamaan $\overline{W_{l}}=\sqrt[n]{M_{i}}, \mathrm{i}=1,2, \ldots, \mathrm{n}$

3. Melakukan normalisasi terhadap $\bar{W}_{i}$ dengan persamaan $\mathrm{W}_{\mathrm{i}}=\bar{W}_{\mathrm{i}} / \sum_{j=1}^{n} \bar{W}_{\mathrm{j}}, \mathrm{i}=1,2, \ldots, \mathrm{n}$

4. Mencari nilai lamda maks. Menurut Saaty [8], mencari $\lambda_{\text {maks }}$ dapat menggunakaan persamaan $\lambda_{\text {maks }}=\sum_{i=1}^{n} \frac{W i}{n * W i}$ 
5. Cek Consistency Index (CI)

Mencari nilai CI (Consistency Index) dengan persamaan CI $=\frac{\lambda_{n n k x}-n}{n-1}$

6. Mencari Nilai RI disesuaiakan dengan nilai Random Index yang dapat dilihat pada Tabel 3 dibawah ini.

\begin{tabular}{|c|c|c|c|c|c|}
\hline $\begin{array}{c}\text { Ordo } \\
\text { Matriks }\end{array}$ & RI & $\begin{array}{c}\text { Ordo } \\
\text { Matriks }\end{array}$ & RI & $\begin{array}{c}\text { Ordo } \\
\text { Matriks }\end{array}$ & RI \\
\hline 1 & 0 & 6 & 1,24 & 11 & 1,51 \\
\hline 2 & 0 & 7 & 1,32 & 12 & 1,48 \\
\hline 3 & 0,58 & 8 & 1,41 & 13 & 1,56 \\
\hline 4 & 0,9 & 9 & 1,45 & 14 & 1,57 \\
\hline 5 & 1,12 & 10 & 1,49 & 15 & 1,59 \\
\hline
\end{tabular}

Gambar 1. Random Index (RI)

7. Mencari CR (Consistency Ratio) $\mathrm{CR}=\frac{G I}{R I}$

Jika nilai $\mathrm{CR}<0.1$ berarti data perbandingan yang dibuat sudah konsisten.

\section{B. ROC (Rank Order Centroid)}

Perhitungan Rank Order Centroid digunakan untuk menentukan bobot pengganti (elicitation weight) dari urutan prioritas atribut yang ditentukan oleh pengambil keputusan, ROC didasarkan pada tingkat kepentingan atau prioritas yang biasanya dibentuk dengan pernyataan "atribut ke-1 lebih penting dari atribut ke-2, yang lebih penting dari kriteria ke-3 dan seterusnya hingga atribut ke-n"(Barron \& Barrett, 1996).

Dalam perhitungan ROC , untuk menentukan bobot maka diberikan aturan : $W_{1} \geq W_{2} \geq W_{3} \geq \ldots \geq$ $W_{n} \geq 0 ; \sum_{j=1}^{n} \bar{W}_{j}=1$

Dimana $W_{1}$ merupakan bobot untuk semua kriteria $C_{1}$, sehingga nilai $W_{1}$ sampai $W_{j}$ dapat ditentukan sebagai berikut:

$$
\begin{aligned}
& W_{1}=\left(1+\frac{1}{2}+\frac{1}{a}+\ldots+\frac{1}{j}\right) / \mathrm{K} \\
& W_{2}=\left(0+\frac{1}{2}+\frac{1}{a}+\ldots+\frac{1}{j}\right) / \mathrm{K} \\
& W_{j}=\left(0+\ldots+0+\frac{1}{j}\right) / \mathrm{K}
\end{aligned}
$$

Secara umum jika $\mathrm{K}$ adalah jumlah kriteria, maka nilai bobot kriteria ke-j dirumuskan dengan mengalikan $1 / \mathrm{K}$ dengan jumlah total $1 / i$, dimana $i=1,2,3 . ., \mathrm{j}$, sebagai berikut :

$$
\mathrm{W}_{\mathrm{j}}=\frac{1}{\mathrm{~K}} \sum_{i=\mathbb{1}}^{\mathrm{K}}\left(\frac{1}{\mathrm{i}}\right)
$$

Keterangan:

$W j=$ nilai pembobotan atribut ke-j

$\mathrm{K}=$ jumlah atribut

$i=$ nilai urutan prioritas atribut

\section{SAW (Simple Additive Weighting)}

Konsep dasar metode SAW adalah mencari penjumlahan terbobot dari rating kinerja pada setiap alternatif pada semua atribut. Metode SAW membutuhkan proses normalisasi matriks keputusan (X) ke dalam suatu skala yang dapat diperbandingkan dengan semua rating alternatif yang ada. Metode SAW mengharuskan pembuat keputusan menentukan bobot bagi setiap atribut. Skor total untuk alternatif diperoleh dengan menjumlahkan seluruh hasil perkalian antara rating dan bobot tiap atribut. Rating tiap atribut harulah dimensi dalam arti telah melewati proses normalisasi matriks sebelumnya(Fishburn, 1967). 
Pada penelitian ini tentang seleksi pemberian beasiswa, maka mahasiswa yang memiliki nilai akhir tertinggi yang akan menjadi prioritas sebagai alternatif terbaik penerima beasiswa PPA ataupun BBP. Terdapat tahapan-tahapan yang harus dilakukan, yaitu :

1. Penentuan nilai kriteria

Perhitungan dilakukan dengan menggunakan persamaan :

$N K=\Sigma(S K * X)$

Keterangan :

NK : Nilai total tiap kriteria

SK : Nilai subkriteria

$\mathrm{X}$ : Besar bobot preferensi

2. Membuat matriks keputusan

Matriks keputusan dibuat berdasarkan jumlah elemen (n) kriteria dan jumlah alternatif.

3. Normalisasi Matriks

Metode SAW membutuhkan proses normalisasi matriks keputusan X ke suatu skala yang dapat diperbandingkan dengan semua rating alternatif yang ada. Perhitungan untuk melakukan normalisasi matriks disesuaikan dengan persamaan

$$
\begin{aligned}
& \mathrm{r}_{\mathrm{ij}}=\frac{x_{\mathrm{i} j}}{\operatorname{MaxXij}} \text { jika atribut termasuk keuntungan } \\
& \mathrm{r}_{\mathrm{ij}}=\frac{\operatorname{MinXij}}{X \mathrm{i} j} \text { jika atribut termasuk biaya }
\end{aligned}
$$

Keterangan :

$r_{i j}=$ rating kinerja ternormalisasi

$\operatorname{Max}_{\mathrm{i}} \quad \mathrm{j} \quad=$ nilai maksimum elemen tiap kriteria

MinX $_{\mathrm{ij}} \quad$ = nilai minimum elemen tiap kriteria

Benefit $\quad=$ jika nilai terbesar adalah yang terbaik

Cost $\quad=$ jika nilai terkecil adalah yang terbaik

4. Perhitungan nilai akhir dan perankingan

Dimana $r_{i j}$ adalah rating kinerja ternormalisasi dari setiap alternatif $A_{i}$ pada atribut $C_{j}, i=1,2, \ldots m$ dan $j$

$=1,2, . .$, n. Nilai preferensi untuk setiap alternatif $\left(\mathrm{V}_{\mathrm{i}}\right)$ diberikan sebagai berikut $: V_{i}=\sum_{j=1}^{n} w_{j} x_{i j}$

Keterangan :

$\mathrm{V}_{\mathrm{i}}=$ rangking untuk setiap alternatif

$\mathrm{w}_{\mathrm{i}}=$ nilai bobot dari setiap kriteria

$\mathrm{r}_{\mathrm{ij}}=$ nilai rating kinerja ternormalisasi

Nilai $V_{\mathrm{i}}$ lebih besar mengindikasikan bahwa alternatif $A_{\mathrm{i}}$ lebih terpilih.

\section{Sensitifitas}

Uji sensitifitas dilakukan untuk mengetahui dan mendapatkan hasil dari perbandingan metode AHP-SAW dan metode ROC-SAW untuk mengetahui metode yang lebih sensitif terhadap perubahan bobot serta perubahan ranking dalam suatu metode(Widaningsih, 2017).

Uji sensitivitas pada penelitian ini berdasarkan nilai rentang terkecil dari beberapa nilai dan variabel yang ada dalam proses regresi, uji sensitivitas tahap pertama dilakukan dengan tiga proses yaitu (Kusmiyanti, Richa Dwi, Suliatun, 2017) :

Pertama, penentuan sensivitas dilakukan dengan mengurangi nilai alternatif pertama dengan nilai alternatif kedua. Secara umum dirumuskan dengan:

Dimana:

$$
\text { Jumlah Sensitivitas }=(X A-X B)
$$

$\mathrm{Xa}=$ Nilai Alternatif Pertama

$\mathrm{Xb}=$ Nilai Alternatif Kedua 
Kedua, penentuan sensivitas dilakukan dengan membagi nilai alternatif pertama dengan jumlah total nilai keseluruhan alternatif. Secara umum dirumuskan dengan:

$$
\text { Jumlah Sensitivitas }=\frac{x i}{\Sigma x}
$$

Dimana:

$\mathrm{Xi}=$ nilai alternatif ke-i

$\mathrm{X}=$ nilai alternatif

Ketiga, penentuan sensitivitas ini dilakukan dengan menjumlahkan nilai alternatif pertama dengan nilai alternatif kedua, lalu dibagi dua. Secara umum dirumuskan dengan:

$$
\text { Jumlah sensitivitas }=\frac{1}{2}(X a+X b)
$$

Dimana:

$\mathrm{Xa}=$ nilai alternatif pertama

$\mathrm{Xb}=$ nilai alternatif kedua

Selanjutnya perhitungan uji sensitifitas menggunakan derajat sensitifitas ( $\mathrm{Sj}$ ) di setiap atribut (C. H. Yeh, 2002)(Kusumadewi \& Hartati, 2007), langkah uji sensitifitas sebagai berikut :

1. Menentukan semua bobot atribut, $\mathrm{Wj}=1$ (nilai awal bobot), dengan $\mathrm{j}=1,2 \ldots \mathrm{n}$ (banyaknya atribut).

2. Merubah bobot atribut dalam range nilai $1-2$, dan menaikkan nilai bobot mulai dari 0,1 dan seterusnya dengan bobot atribut yang lainnya tetap sesuai bobot awal.

3. Mengimplementasikan pada metode AHP-SAW dan metode ROC-SAW untuk bobot atribut yang telah ditentukan pada Tabel 4.

4. Menghitung prosentase perubahan ranking dengan cara membandingkan seberapa perubahan ranking yang terjadi jika dibandingkan dengan kondisi pada saat bobot sama yaitu $\mathrm{Wj}=1$ (nilai bobot awal).

\section{E. Persentase Perubahan Ranking}

Persentase perubahan ranking metode AHP-SAW dan ROC-SAW digunakan untuk melihat hasil akhir dari proses analisis sentivitas, perhitungan persentase menggunakan rumus sebagai berikut (Syaka \& Mulyanto, 2019):

$$
\frac{T}{i x A} \times 100
$$

Keterangan :

$\mathrm{T}=$ total akhir perubahan ranking alternatif

$\mathrm{I}=$ total perubahan bobot

$\mathrm{A}=$ jumlah atribut atau kriteria yang digunakan

\section{Hasil dan Pembahasan}

Data yang digunakan dalam penelitian ini adalah data primer dan sekunder yaitu data pendaftar beasiswa PPA mahasiswa STMIK STIKOM Indonesia tahun 2016/2017 sebanyak 22 mahasiswa dari 2 program studi yaitu teknik informatika dan sistem komputer sebagai alternatif penerima beasiswa(I Gede Iwan Sudipa, 2018). Syarat-syarat yang dijadikan parameter penelitian atau kriteria yaitu IPK (C1), Prestasi Akademik (C2), Jumlah Semester (C3), Prestasi Non Akademik (C4), Keaktifan Organisasi (C5), Jumlah Seminar bidang Teknologi Informasi yang diikuti (C6), Jumlah Penghasilan Orangtua (C7), Jumlah Tanggungan Orangtua(C8), dan Daya Listrik (C9). Sesuai dengan teknik analisis, langkah pertama yang dilakukan adalah menentukan prioritas bobot dengan metode AHP dan metode ROC : 
Tabel 2. Matriks Perbandingan Berpasangan Kriteria

\begin{tabular}{cccccccccc}
\hline Kriteria & C1 & C2 & C3 & C4 & C5 & C6 & C7 & C8 & C9 \\
\hline C1 & 1 & 2 & 3 & 2 & 2 & 3 & 3 & 3 & 3 \\
C2 & 2 & 1 & 3 & 2 & 2 & 3 & 3 & 3 & 3 \\
C3 & 0,5 & 0,5 & 1 & 2 & 2 & 2 & 3 & 3 & 3 \\
C4 & 0,33 & 0,33 & 0,5 & 1 & 2 & 3 & 3 & 3 & 3 \\
C5 & 0,5 & 0,5 & 0,5 & 0,5 & 1 & 2 & 2 & 2 & 2 \\
C6 & 0,5 & 0,5 & 0,5 & 0,33 & 0,5 & 1 & 2 & 2 & 2 \\
C7 & 0,33 & 0,33 & 0,33 & 0,33 & 0,5 & 0,5 & 1 & 2 & 3 \\
C8 & 0,33 & 0,33 & 0,33 & 0,33 & 0,5 & 0,5 & 0,5 & 1 & 2 \\
C9 & 0,33 & 0,33 & 0,33 & 0,33 & 0,5 & 0,5 & 0,33 & 0,5 & 1 \\
\hline Kriteria & C1 & C2 & C3 & C4 & C5 & C6 & C7 & C8 & C9 \\
\hline C1 & 1 & 2 & 3 & 2 & 2 & 3 & 3 & 3 & 3 \\
C2 & 2 & 1 & 3 & 2 & 2 & 3 & 3 & 3 & 3 \\
C3 & 0,5 & 0,5 & 1 & 2 & 2 & 2 & 3 & 3 & 3 \\
C4 & 0,33 & 0,33 & 0,5 & 1 & 2 & 3 & 3 & 3 & 3 \\
C5 & 0,5 & 0,5 & 0,5 & 0,5 & 1 & 2 & 2 & 2 & 2 \\
C6 & 0,5 & 0,5 & 0,5 & 0,33 & 0,5 & 1 & 2 & 2 & 2 \\
\hline
\end{tabular}

Untuk menentukan bobot prioritas kriteria menggunakan rumus(3), sehingga bobot yang dihasilkan sebagai berikut :
a. $\operatorname{IPK}(\mathrm{C} 1)=0,22141$
b. Prestasi Akademik (C2) =0,189802
c. Jumlah Semester (C3) $=0,135876$
d. Prestasi Non Akademik (C4)=0,133335
e. Keaktifan Organisasi (C5) = 0,095452
f. Jumlah Seminar bidang Teknologi Informasi yang diikuti (C6) = 0,071481
g. Jumlah Penghasilan Orangtua (C7) $=0,061277$
h. Jumlah Tanggungan Orangtua(C8)=0,050215
i. Daya Listrik $(\mathrm{C} 9)=0,041151$

Untuk mencari nilai $\lambda_{\text {maks }}$ menggunakan rumus(4), perhitungannya sebagai berikut : $\lambda_{\text {maks }}=((1+2$ $+0,5+0,33+0,5+0,5+0,33+0,33+0,33) \times 0,22141)+((2+1+0,5+0,33+0,5+0,5+0,33+0,33+0,33) \times$ $0,189802)+((3+3+1+0,5+0,5+0,50,33+0,33+0,33) \times 0,135876)+((2+2+2+1+0,5+0,33+0,33$ $+0,33+0,33) \times 0,133335)+)+((2+2+2+2+1+0,5+0,5+0,5+0,5) \times 0,0,095452)+((3+3+2+3+$ $2+1+0,5+0,5+0,5) \times 0,071481)+((3+3+3+3+2+2+1+0,5+0,33) \times 0,061277)+((3+3+3+3$ $+2+2+2+1+0,5) \times 0,050215)+((3+3+3+3+2+2+3+2+1) \times 0.041151)=9,601927$ berikut

Selanjutnya menghitung Consistency Index (CI) menggunakan rumus(5), perhitungannya sebagai

$$
C I=\frac{9,601927-9}{9-1}=0,07
$$

Menghitung Consistency Ratio (CR) menggunakan rumus(6). Ratio index (RI) yang digunakan adalah 1,45 karena jumlah kriteria $(\mathrm{n})=9$, perhitungan CR sebagai berikut :

$$
\mathrm{CR}=\frac{0,07}{1,45}=0,05, \text { nilai CR menunjukkan } \leq 0,1 \text { yang menunjukkan konsisten } .
$$

Untuk menentukan bobot kriteria dengan model ROC maka urutan peringkat atribut atau kriteria sudah diketahui dan sudah diprioritas dari kriteria dengan prioritas ke-1, prioritas ke-2 sampai prioritas ke-n(I Gede Iwan Sudipa, 2018). Perhitungan Bobot Kriteria dengan metode ROC menggunakan rumus (8) dan rumus (9), sehingga didapatkan hasil nilai bobot setiap kriteria seperti ditunjukkan pada Tabel 3, sebagai berikut. 
Tabel 3. Hasil Perhitungan Bobot Metode ROC

\begin{tabular}{ll}
\hline Kriteria & $\mathrm{W}_{1}=\frac{1}{9} \times\left(\frac{1}{1}+\frac{1}{2}+\frac{1}{9}+\frac{1}{4}+\frac{1}{5}+\frac{1}{6}+\frac{1}{7}+\frac{1}{9}+\frac{1}{9}\right)=0,31433$ \\
C1 & $\mathrm{W}_{2}=\frac{1}{5} \times\left(\frac{1}{2}+\frac{1}{9}+\frac{1}{4}+\frac{1}{5}+\frac{1}{6}+\frac{1}{7}+\frac{1}{9}+\frac{1}{9}\right)=0,20322$ \\
C2 & $\mathrm{W}_{3}=\frac{1}{5} \times\left(\frac{1}{9}+\frac{1}{4}+\frac{1}{5}+\frac{1}{6}+\frac{1}{7}+\frac{1}{9}+\frac{1}{9}\right)=0,14766$ \\
C4 & $\mathrm{W}_{4}=\frac{1}{5} \times\left(\frac{1}{4}+\frac{1}{5}+\frac{1}{6}+\frac{1}{7}+\frac{1}{9}+\frac{1}{9}\right)=0,11063$ \\
C5 & $\mathrm{W}_{5}=\frac{1}{5} \times\left(\frac{1}{5}+\frac{1}{6}+\frac{1}{7}+\frac{1}{9}+\frac{1}{9}\right)=0,08285$ \\
C6 & $\mathrm{W}_{6}=\frac{1}{5} \times\left(\frac{1}{6}+\frac{1}{7}+\frac{1}{9}+\frac{1}{9}\right)=0,06063$ \\
C7 & $\mathrm{W}_{7}=\frac{1}{5} \times\left(\frac{1}{7}+\frac{1}{9}+\frac{1}{9}\right)=0,04211$ \\
C8 & $\mathrm{W}_{8}=\frac{1}{5} \times\left(\frac{1}{9}+\frac{1}{9}\right)=0,02623$ \\
C9 & $\mathrm{W}_{9}=\frac{1}{5} \times\left(\frac{1}{9}\right)=0,01235$ \\
\hline
\end{tabular}

Tabel 4. Hasil Nilai Bobot Metode AHP dan Metode ROC

\begin{tabular}{ccccc}
\hline Kriteria & Nilai Bobot AHP & Nilai Bobot ROC & $\begin{array}{c}\text { Perbandingan } \\
\text { bobot }\end{array}$ & $\begin{array}{c}\text { Perbandingan } \\
\text { bobot (\%) }\end{array}$ \\
\hline C1 & 0,22141 & 0,31433 & 0,09292 & $9 \%$ \\
C2 & 0,189802 & 0,20322 & 0,013418 & $1 \%$ \\
C3 & 0,13588 & 0,14766 & 0,01178 & $1 \%$ \\
C4 & 0,133335 & 0,11063 & 0,022705 & $2 \%$ \\
C5 & 0,09545 & 0,08285 & 0,0126 & $1 \%$ \\
C6 & 0,07148 & 0,06063 & 0,01085 & $2 \%$ \\
C7 & 0,06128 & 0,04211 & 0,01917 & $2 \%$ \\
C8 & 0,05022 & 0,02623 & 0,02399 & $3 \%$ \\
C9 & 0,04115 & 0,01235 & 0,0288 & \\
\hline
\end{tabular}

Perhitungan bobot dihitung dengan rumus (1) sampai (9). Perbandingan bobot didapatkan dengan menghitung selisih kenaikan bobot tiap kriteria yang dihasilkan oleh metode AHP dan ROC.

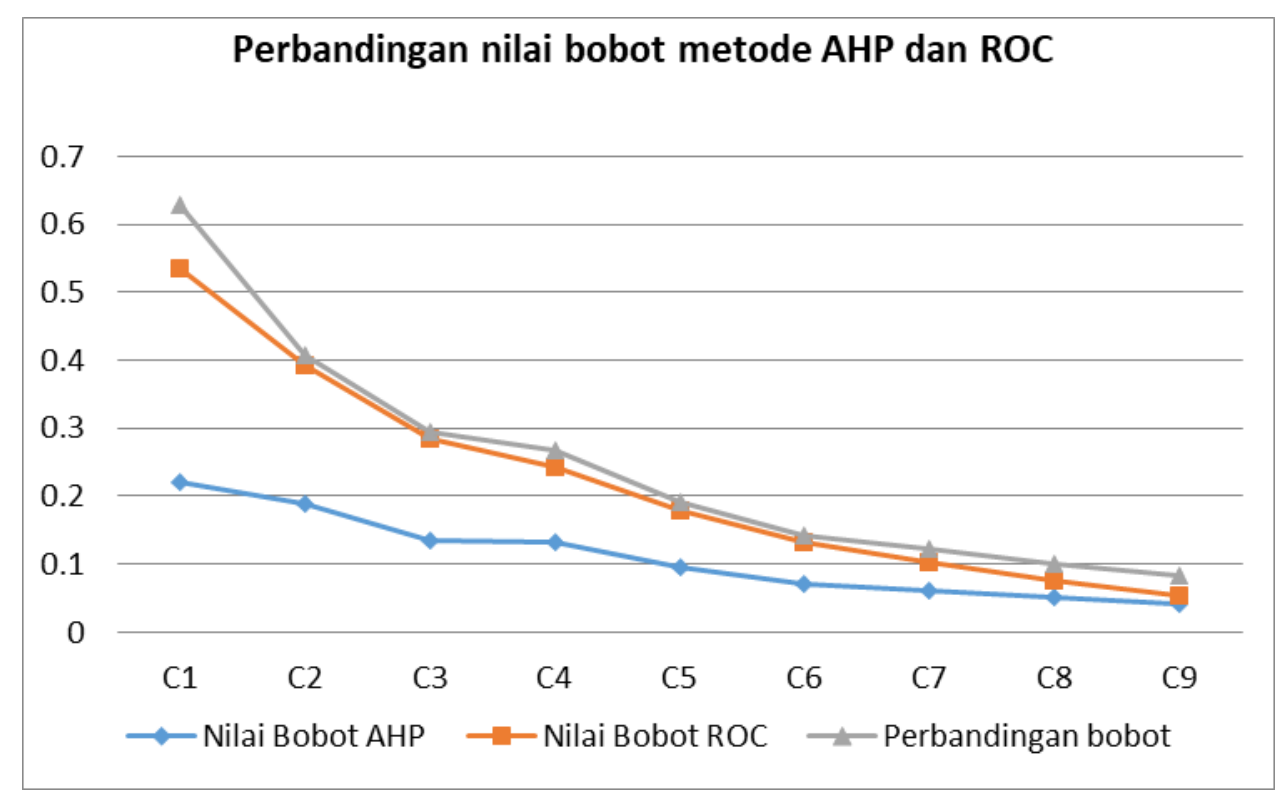

Gambar 2. Perbandingan Nilai Bobot Metode AHP dan ROC 
Pada Tabel 5 menunjukkan data mahasiswa pemohon beasiswa PPA tahun 2017 yang terdiri dari 22 mahasiswa dan 9 kriteria penilaian, nilai alternatif pada setiap kriteria sudah diskoring kedalam angka.

Tabel 5. Data Mahasiswa Pemohon Beasiswa PPA tahun 2017

\begin{tabular}{|c|c|c|c|c|c|c|c|c|c|}
\hline \multirow{2}{*}{ Alternatif } & \multicolumn{9}{|c|}{ Kriteria } \\
\hline & C1 & $\mathrm{C2}$ & C3 & C4 & C5 & C6 & C7 & C8 & C9 \\
\hline Mahesa & 3,81 & 0,91333333 & 6 & 0,0625 & 2 & 1 & 5 & 1 & 2 \\
\hline Ester & 3,95 & 0,31333333 & 6 & 0,0625 & 2 & 2 & 3 & 1 & 2 \\
\hline Lely & 3,82 & 0,04 & 4 & $\begin{array}{c}0,29166 \\
7\end{array}$ & 2 & 2 & 1 & 2 & 2 \\
\hline Lestari & 3,71 & 0,51333333 & 4 & 0,0625 & 2 & 2 & 2 & 2 & 2 \\
\hline Lina & 3,9 & 0,04 & 4 & 0,4375 & 2 & 2 & 2 & 2 & 2 \\
\hline Yoseph & 3,75 & 0,04 & 4 & $\begin{array}{c}0,27083 \\
3\end{array}$ & 2 & 1 & 3 & 2 & 2 \\
\hline Julius & 3,79 & 0,04 & 4 & $\begin{array}{c}0,27083 \\
3\end{array}$ & 2 & 1 & 1 & 3 & 2 \\
\hline Christopher & 3,86 & 0,04 & 6 & $\begin{array}{c}1,04166 \\
7\end{array}$ & 2 & 1 & 2 & 2 & 2 \\
\hline Rahmawati & 3,58 & 0,04 & 6 & $\begin{array}{c}0,54166 \\
7\end{array}$ & 2 & 2 & 1 & 1 & 2 \\
\hline Jonathan & 3,38 & 0,04 & 6 & $\begin{array}{c}2,08333 \\
3\end{array}$ & 2 & 1 & 1 & 1 & 2 \\
\hline Yusuf & 3,52 & 1,28333333 & 4 & 0,0625 & 2 & 2 & 2 & 2 & 2 \\
\hline Dian & 3,48 & 0,04 & 6 & $\begin{array}{c}0,27083 \\
3\end{array}$ & 2 & 2 & 1 & 1 & 2 \\
\hline Ayudani & 3,88 & 0,47 & 4 & 0,0625 & 2 & 2 & 3 & 2 & 2 \\
\hline Ita Miranti & 3,65 & 0,04 & 4 & 1,5625 & 2 & 2 & 1 & 3 & 2 \\
\hline Yulia & 3,66 & 0,04 & 4 & $\begin{array}{c}0,27083 \\
3\end{array}$ & 2 & 2 & 2 & 2 & 2 \\
\hline Wirawan & 3,7 & 0,18 & 6 & 0,0625 & 2 & 1 & 3 & 2 & 2 \\
\hline Dessie & 3,51 & 0,04 & 4 & $\begin{array}{c}0,29166 \\
7\end{array}$ & 2 & 2 & 5 & 2 & 2 \\
\hline Juniastini & 3,96 & 0,18 & 4 & 0,0625 & 2 & 2 & 2 & 3 & 2 \\
\hline Selfiana & 3,69 & 0,31333333 & 4 & 0,0625 & 2 & 2 & 2 & 2 & 2 \\
\hline Prasetya & 3,36 & 0,18 & 6 & 0,0625 & 2 & 2 & 3 & 2 & 2 \\
\hline Caniartana & 3,37 & 0,04 & 4 & 0,0625 & 2 & 1 & 2 & 2 & 2 \\
\hline Juliana & 3,34 & 0,04 & 4 & 0,0625 & 2 & 1 & 2 & 1 & 2 \\
\hline
\end{tabular}

Untuk menentukan hasil akhir perankingan maka digunakan metode SAW dengan rumus (10) sampai (12) sehingga didapatkan hasil perankingan pada Tabel 6, sebagai berikut:

Tabel 6. Hasil Perankingan Metode AHP-SAW dan Metode ROC-SAW

\begin{tabular}{lcccc}
\hline \multicolumn{1}{c}{ Alternatif } & $\begin{array}{c}\text { Hasil Akhir Metode AHP- } \\
\text { SAW }\end{array}$ & Ranking & $\begin{array}{c}\text { Hasil Akhir Metode } \\
\text { ROC-SAW }\end{array}$ & Ranking \\
\hline Mahesa & 0,722793073 & 3 & 0,7744 & 2 \\
Ester & 0,685792868 & 6 & 0,703972 & 3 \\
Lely & 0,62321768 & 11 & 0,605219 & 17 \\
Lestari & 0,641766946 & 9 & 0,667694 & 8 \\
Lina & 0,60638556 & 14 & 0,627735 & 14 \\
Yoseph & 0,541378684 & 20 & 0,585085 & 19 \\
Julius & 0,576097315 & 18 & 0,58016 & 20 \\
Christopher & 0,652367745 & 8 & 0,675547 & 6 \\
Rahmawati & 0,696198593 & 4 & 0,63992 & 12 \\
Jonathan & 0,747943669 & 1 & 0,675596 & 5 \\
Yusuf & 0,745024939 & 2 & 0,774544 & 1 \\
Dian & 0,673273881 & 7 & 0,617601 & 15
\end{tabular}




\begin{tabular}{lcccc}
\hline \multicolumn{1}{c}{ Alternatif } & $\begin{array}{c}\text { Hasil Akhir Metode AHP- } \\
\text { SAW }\end{array}$ & Ranking & $\begin{array}{c}\text { Hasil Akhir Metode } \\
\text { ROC-SAW }\end{array}$ & Ranking \\
\hline Ayudani & 0,634650189 & 10 & 0,682748 & 4 \\
Ita Miranti & 0,686677889 & 5 & 0,667952 & 7 \\
Yulia & 0,582299971 & 17 & 0,599834 & 18 \\
Wirawan & 0,591247276 & 16 & 0,641442 & 11 \\
Dessie & 0,556863479 & 19 & 0,6143 & 16 \\
Juniastini & 0,598076463 & 15 & 0,643497 & 10 \\
Selfiana & 0,611069181 & 12 & 0,634436 & 13 \\
Prasetya & 0,607977826 & 13 & 0,644769 & 9 \\
Caniartana & 0,517011603 & 22 & 0,535437 & 21 \\
Juliana & 0,540441754 & 21 & 0,524312 & 22 \\
\hline & & \multicolumn{2}{c}{ Sumber data diolah 2017 }
\end{tabular}

Perbedaan hasil disebabkan oleh hasil perhitungan bobot yang dihasilkan oleh metode AHP dan Metode ROC, sehingga memberikan perbedaan ketika digunakan dalam perhitungan akhir metode SAW, dapat dilihat pada pada hasil perhitungan metode AHP-SAW urutan ranking 10 mahasiswa terbaik yaitu : Jonathan $>$ Yusuf $>$ Mahesa $>$ Rahmawati $>$ Ita Miranti $>$ Ester $>$ Dian $>$ Cristopher $>$ Lestari $>$ Ayudani

Sedangkan untuk hasil perhitungan ROC-SAW urutan ranking 10 mahasiswa terbaik yaitu : Yusuf $>$ Mahesa $>$ Ester $>$ Ayudani $>$ Jonathan $>$ Cristopher $>$ Ita Miranti $>$ Lestari $>$ Prasetya $>$ Juniastini

Terdapat perbedaan hasil perankingan dikarenakan perbedaan bobot kriteria yang dihasilkan oleh metode AHP dan ROC, sehingga mempengaruhi nilai akhir 10 alternatif mahasiswa terbaik.

\section{A. Analisis Sensitivitas}

Tahap pertama dilakukan pengujian analisis sensitivitas untuk metode AHP-SAW dan ROC-SAW pada Tabel 7, pengujian analisis sensitivitas akan dilakukan melalui tiga proses sesuai dengan rumus (13) sampai (16), sehingga didapatkan hasil sebagai berikut :

Tabel 7. Hasil Uji Sensitivitas

\begin{tabular}{lccc}
\hline Metode & Sensitivitas I & Sensitivitas II & Sensitivitas III \\
\hline AHP-SAW & 0.002919 & 1.07355 & 0.746484 \\
ROC-SAW & 0.000144 & 0.054869 & 0.774472 \\
\hline
\end{tabular}

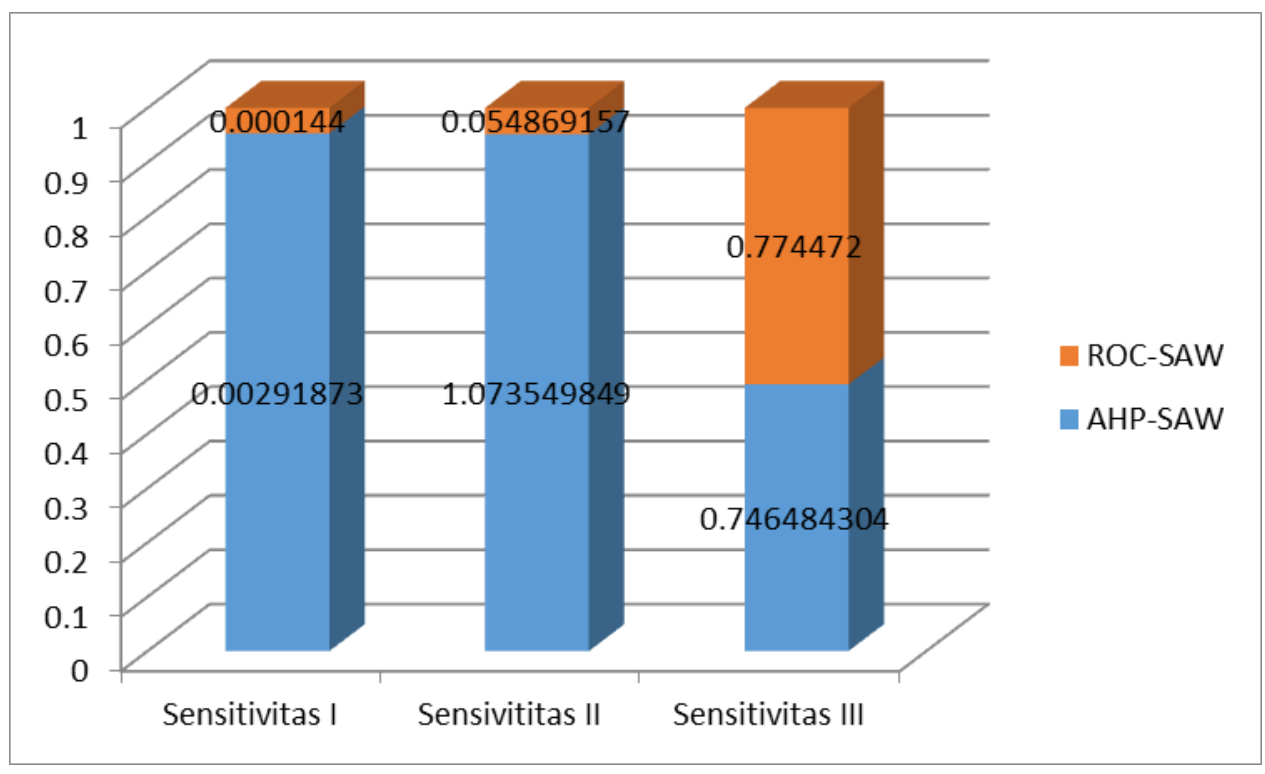

Gambar 3. Hasil Nilai Sensitvitas

Dari gambar 2 dapat diketahui bahwa dari tiga proses sensitivitas bahwa nilai sensitivitas terkecil didapatkan metode ROC-SAW yaitu sensitivitas I dengan nilai 0.000144 , sehingga metode ROCSAW lebih sesuai untuk kasus yang diselesaikan. 
Analisis sensitivitas selanjutnya dilakukan dengan menggunakan derajat sensitifitas (Sj) di setiap atribut, nilai setiap bobot kriteria akan dirubah dengan rentang $1-2$, dengan jumlah $\mathrm{W}=1$. Perubahan bobot kriteria dimulai dengan menambahkan 0.5 kemudian 1 pada kriteria ke-1 dan selanjutnya, sementara kriteria lainnya masih menggunakan bobot awal. Perubahan bobot ini ditujukan untuk mengetahui perubahan ranking pada setiap metode.

Jumlah prosentase perubahan ranking dengan metode AHP-SAW dan ROC-SAW dalam kasus pemberian beasiswa, dapat dilihat pada tabel berikut :

Tabel 8. Hasil Perubahan Ranking

\begin{tabular}{lcc}
\hline \multirow{2}{*}{ Bobot Kriteria } & \multicolumn{2}{c}{ Jumlah Perubahan Ranking } \\
\cline { 2 - 3 } & AHP-SAW & ROC-SAW \\
\hline Kriteria 1 + (0,5) & 17 & 15 \\
Kriteria 1 + (1) & 16 & 17 \\
Kriteria 2 + (0,5) & 15 & 18 \\
Kriteria 2 + (1) & 14 & 17 \\
Kriteria 3 + (0,5) & 13 & 19 \\
Kriteria 3 + (1) & 13 & 18 \\
Kriteria 4 + (0,5) & 14 & 18 \\
Kriteria 4 + (1) & 16 & 17 \\
Kriteria 5 + (0.5) & 19 & 19 \\
Kriteria 5 + (1) & 19 & 19 \\
Kriteria 6 + (0,5) & 17 & 18 \\
Kriteria 6 + (1) & 17 & 19 \\
Kriteria 7 + (0,5) & 18 & 19 \\
Kriteria 7 + (1) & 17 & 19 \\
Kriteria 8 + (0,5) & 13 & 19 \\
Kriteria 8 + (1) & 14 & 18 \\
Kriteria 9 + (0,5) & 19 & 19 \\
Kriteria 9 + (1) & 19 & 19 \\
\hline \multicolumn{1}{c}{ Jumlah } & $\mathbf{2 9 0}$ & $\mathbf{3 2 7}$ \\
\hline
\end{tabular}

\section{B. Perhitungan Total Perubahan Ranking}

Menghitung total perubahan ranking yaitu menjumlahkan perubahan ranking metode AHP-SAW dan ROC-SAW pada setiap perubahan bobot kriteria sesuai dengan rumus(16), sehingga didapatkan hasil sebagai berikut:

Presentase perubahan ranking metode AHP-SAW

$$
\frac{290}{9 \times 20} \times 100=80,56 \%
$$

Persentase perubahan ranking metode ROC -SAW

$$
\frac{327}{8 \times 20} \times 100=90,83 \%
$$

\section{Simpulan dan Saran}

Berdasarkan analisis dan pembahasan yang telah dilakukan maka dapat diberikan kesimpulan, yaitu : 1) Hasil perankingan mahasiswa pemohon beasiswa tahun 2017 menggunakan metode AHP-SAW mendapatkan alternatif terbaik yaitu Jonathan dengan nilai 0.747943669 dan alternatif terbaik menggunakan metode ROC-SAW yaitu Yusuf dengan nilai 0.774544. Perbedaan hasil perankingan disebabkan karena bobot preferensi kriteria yang dihasilkan berbeda dari metode AHP dan ROC. 2) Pengujian analisis sensivitas dengan menggunakan tiga proses menunjukkan metode ROC-SAW memiliki sentivitas lebih kecil dibandingkan metode AHP-SAW yaitu nilai terkecil 0.000144, sehingga metode ROCSAW lebih sesuai untuk kasus yang diselesaikan. 3) Pengujian analisis sensitivitas dengan perubahan bobot dengan 18 percobaan perubahan bobot dengan jumlah kriteria yang berbeda menyatakan bahwa metode ROC-SAW menghasilkan jumlah perankingan sebesar 290 dengan jumlah persentase $80.56 \%$ dan 
metode AHP-SAW menghasilkan jumlah perubahan ranking sebesar 327 dengan jumlah persentase 90.83\%. Metode ROC-SAW memiliki perubahan ranking dan sensitivitas yang lebih tinggi dibandingkan dengan AHP-SAW.

Saran yang dapat diberikan yaitu adanya perbandingan dengan metode MCDM (Multi Criteria Decision Making) lainnya dan dapat dilakukan analisis sensitivitas setiap metode serta melakukan analisis sensitivitas kriteria.

\section{Daftar Rujukan}

Barron, F. H., \& Barrett, B. E. (1996). The efficacy of SMARTER - Simple Multi-Attribute Rating Technique Extended to Ranking. Acta Psychologica, 93(1-3), 23-36.

Chun, Y., Huang, Y. Y., \& Wang, Z. Q. (2009). Topsis-AHP-simulation method and its application in operational capability evaluation. 2009 Chinese Control and Decision Conference, CCDC 2009, 2954-2957.

Fishburn, P. C. (1967). Letter to the Editor-Additive Utilities with Incomplete Product Sets: Application to Priorities and Assignments. Operations Research, 15(3), 537-542.

I Gede Iwan Sudipa. (2018). Decision Support System Dengan Metode AHP, SAW dan ROC Untuk Penentuan Pemberian Beasiswa (Studi Kasus STMIK STIKOM INDONESIA). Jurnal Teknologi Informasi dan Komputer, 4(1), 18-30.

Jenderal, D., Dan, P., Riset, K., \& Tinggi, D. A. N. P. (2015). Pedoman umum beasiswa dan bantuan biaya pendidikan peningkatan prestasi akademik (ppa).

Kusmiyanti, Richa Dwi, Suliatun, M. (2017). Analisis Sensitifitas Model SMART-AHP dengan SMARTERROC sebagai Pengambilan Keputusan Multi Kriteria, 18-19.

Kusumadewi, S., \& Hartati, S. (2007). Sensitivity analysis of multi-attribute decision making methods in clinical group decision support system. 2007 International Conference on Intelligent and Advanced Systems, ICIAS 2007, 301-304.

Syaka, A. K., \& Mulyanto, A. (2019). Analisis Perbandingan Sensitivitas AHP dan WP dalam Pemilihan Biro Perjalanan Umrah di Yogyakarta, 3(3), 38-49.

Widaningsih, S. (2017). Analisis Sensitivitas Metode AHP Dengan Menggunakan Weighted Sum Model ( WSM ) Pada Simulasi Pemilihan Investasi Sektor Financial. Jurnal Informatika.

Yeh, C. H. (2002). A Problem-based Selection of Multi-attribute Decision-making Methods. International Transactions in Operational Research, 9(2), 169-181.

Yeh, C. H. (2003). The Selection of Multiattribute Decision Making Methods for Scholarship Student Selection. International Journal of Selection and Assessment, 11(4), 289-296.

Yeh, C., \& Willis, R. J. (2001). A validation procedure for multicriteria analysis : application to the selection of scholarship students, 6, 39-52. 